\title{
Genetic Detection of Pseudomonas spp. in Commercial Amazonian Fish
}

\author{
Alba Ardura ${ }^{1{ }^{*},}$, Ana R. Linde ${ }^{2}$ and Eva Garcia-Vazquez ${ }^{1}$ \\ 1 Department of Functional Biology, University of Oviedo. C/Julian Claveria s/n, \\ Oviedo 33006, Spain; E-Mail: egv@uniovi.es \\ 2 Laboratory of Toxicology, National School of Public Health, Fundaçao Oswaldo Cruz, \\ Rio de Janeiro 21041, Brazil; E-Mail: linde14@yahoo.com \\ * Author to whom correspondence should be addressed; E-Mail: alarguti@hotmail.com; \\ Tel.: +34-985-102-726; Fax: +34-985-103-534.
}

Received: 23 June 2013; in revised form: 23 July 2013 / Accepted: 15 August 2013 /

Published: 29 August 2013

\begin{abstract}
Brazilian freshwater fish caught from large drainages like the River Amazon represent a million ton market in expansion, which is of enormous importance for export to other continents as exotic seafood. A guarantee of bacteriological safety is required for international exports that comprise a set of different bacteria but not any Pseudomonas. However, diarrhoea, infections and even septicaemia caused by some Pseudomonas species have been reported, especially in immune-depressed patients. In this work we have employed PCR-based methodology for identifying Pseudomonas species in commercial fish caught from two different areas within the Amazon basin. Most fish caught from the downstream tributary River Tapajòs were contaminated by five different Pseudomonas species. All fish samples obtained from the River Negro tributary (Manaus markets) contained Pseudomonas, but a less diverse community with only two species. The most dangerous Pseudomonas species for human health, P. aeruginosa, was not found and consumption of these fish (from their Pseudomonas content) can be considered safe for healthy consumers. As a precautionary approach we suggest considering Pseudomonas in routine bacteriological surveys of imported seafood.
\end{abstract}

Keywords: Amazon River; Pseudomonas; molecular tests; commercial fish; food safety 


\section{Introduction}

Brazil contains a rich biodiversity of animal and plant taxa distributed at varied latitudes, and could open a new international market for high quality food products, perhaps targeting delicatessen shops and specialized restaurants. Such a market would be exclusive of Brazil because many species from some regions, like the Amazon, are unique and endemic. Due to their enormous diversity [1,2], Amazonian fishes represent a potentially interesting sector for export. Tools for labeling these fishes are currently being developed [3], aimed at enabling Amazonian fish introduction in demanding markets like the European one, where the normatives on traceability and food security control are strict (e.g., European Directives CE-178/2002; CE-1759/2006).

Introduction of exotic species in a new market encompasses some potential risks. One of them is introduction of parasites or pathogens endemic of their native region [4]. Control of such pathogens in the importer country may not be required if they are normally absent from local food. An example applicable to the fish trade could be Pseudomonas. These bacteria constitute a part of the normal fish microbiota, but are opportunistic and may become infectious and spread diseases in stressed fish [5]. Pseudomonas can be a problem for human consumers too. They appear in processes of seafood spoilage [6,7] and in ready-to-eat products [8]. In some conditions they can become human pathogens and cause infection. Many pathogeneses of Pseudomonas in humans, generally caused by only one species (most frequently $P$. aeruginosa), are health-care associated illnesses $[9,10]$, and the risk of disease by ingestion in healthy consumers has been considered generally low in developed countries [11]. However, such risk exists and can be serious depending on the circumstances. Contamination with enterotoxigenic Pseudomonas has been reported from food and drinking water samples in some countries [12]. Jertborn and Svennerholm [13] have discovered enterotoxin-producing Pseudomonas in Swedish travellers with diarrhoea, somewhat more frequently in travellers visiting Africa, Asia and Latin America. In association with other bacteria they can cause severe cholera symptoms in healthy adults [14]. Even when their enterotoxigenic activity is weak they can still produce diarrhoea in immunodeficient individuals [15]. In addition they can cause skin problems; their presence in cosmetics is considered a health threat in the U.S. [16], and have produced outbreaks of skin infections [17]. Therefore there are infection risks when manipulating contaminated seafood.

Notwithstanding the information provided above, Pseudomonas species are not catalogued as a foodborne pathogen in Europe and other regions. Control tests of imported fish and shellfish include various bacterial species like Escherichia coli, C. botulinum, Listeria monocytogenes, Staphylococcus aureus, Enterobacter sakazakii and Salmonella sp., but not Pseudomonas spp. (e.g., European Council Directive 1991, 1995 and Council Directive 1998; Canadian Food Inspection Agency [18], European Comission [19], American Food Safety and Inspection Service (FSIS) [20].

The aim of this study was to investigate the presence of Pseudomonas spp. in samples of commercial fish sold in Brazilian markets from two different Amazonian states (Table 1): the River Tapajós (Para) and the River Negro (Amazonas). The results may inform about the convenience of including these bacteria in routine controls for Brazilian fish exports as well as in local markets. The molecular tools used in this study were PCR-amplification with Pseudomonas-specific primers and sequencing 16S rRNA genes. This type of methodology is highly sensitive and has been employed in other surveys of foodborne bacteria [21,22]. 
Table 1. Samples analyzed, fish species with their common names and Pseudomonas species identified.

\begin{tabular}{|c|c|c|c|c|}
\hline Sample & Origin & Fish spp. & Common name & Pseudomonas species \\
\hline $\mathrm{T} 1$ & Tapajós & Prochilodus nigricans & Curimatá & Pseudomonas psychrophila \\
\hline $\mathrm{T} 2$ & Tapajós & Cetopsis candiru & Candiru & Pseudomonas spp. \\
\hline $\mathrm{T} 3$ & Tapajós & Leporinus piau & Piau & Pseudomonas psychrophila \\
\hline $\mathrm{T} 4$ & Tapajós & Leporinus piau & Piau & Pseudomonas syringae \\
\hline T5 & Tapajós & Serrasalmus rhombeus & Piranha & Pseudomonas fragi \\
\hline T6 & Tapajós & Leporinus piau & Piau & Pseudomonas fluorescens \\
\hline $\mathrm{T} 7$ & Tapajós & Ageneiosus brevifilis & Bocudo & Pseudomonas fluorescens \\
\hline $\mathrm{T} 8$ & Tapajós & Leporinus piau & Piau & Pseudomonas psychrophila \\
\hline T9 & Tapajós & Leporinus piau & Piau & Pseudomonas syringae \\
\hline $\mathrm{T} 10$ & Tapajós & Leporinus piau & Piau & Pseudomonas fluorescens \\
\hline $\mathrm{T} 11$ & Tapajós & Leporinus piau & Piau & Pseudomonas spp. \\
\hline $\mathrm{T} 12$ & Tapajós & Leporinus piau & Piau & Pseudomonas psychrophila \\
\hline $\mathrm{T} 13$ & Tapajós & Prochilodus nigricans & Curimatá & Pseudomonas psychrophila \\
\hline $\mathrm{T} 14$ & Tapajós & Leporinus piau & Piau & Pseudomonas fragi \\
\hline $\mathrm{T} 15$ & Tapajós & Leporinus piau & Piau & Pseudomonas psychrophila \\
\hline $\mathrm{T} 16$ & Tapajós & Leporinus piau & Piau & Pseudomonas putida \\
\hline $\mathrm{T} 17$ & Tapajós & Leporinus piau & Piau & - \\
\hline $\mathrm{T} 18$ & Tapajós & Leporinus piau & Piau & - \\
\hline M1 & Negro & Chaetobranchopsis orbicularis & Acará branco & Pseudomonas putida \\
\hline M2 & Negro & Astonotus ocellatus & Acará-açú & Pseudomonas putida \\
\hline M3 & Negro & Astonotus ocellatus & Acará-açú & Pseudomonas putida \\
\hline M4 & Negro & Astonotus ocellatus & Acará-açú & Pseudomonas putida \\
\hline M5 & Negro & Osteoglossum bicirrhosum & Aruanà & Pseudomonas putida \\
\hline M6 & Negro & Brachypatystoma rousseauxii & Dourada & Pseudomonas putida \\
\hline M7 & Negro & Semaprochilodus insignis & Jaraquí & Pseudomonas putida \\
\hline M8 & Negro & Plagioscion squamosissimus & Pescada & Pseudomonas putida \\
\hline M9 & Negro & Phractocephalus hemioliopterus & Pirarara & Pseudomonas psychrophila \\
\hline M10 & Negro & Pseudoplatystoma fasciatum & Surubim & Pseudomonas putida \\
\hline M11 & Negro & Cichla temensis & Tucunaré & Pseudomonas putida \\
\hline M12 & Negro & Cichla temensis & Tucunaré & Pseudomonas putida \\
\hline
\end{tabular}

\section{Experimental Section}

\subsection{Sampling}

The 30 fish samples analyzed (Table 1) were obtained from two different tributaries within the Amazon basin (Figure 1): the River Negro (Manaus markets; $n=12)$ and the River Tapajós $(n=18)$, and were directly purchased from fishermen in local harbors and markets. All fish specimens were morphologically identified in situ by visual inspection and taxonomically classified employing standard taxonomic guides. After cleaning the fish surface with ethanol, samples of muscle (the edible tissue) were excised in situ with sterilized blades and tweezers and immediately stored in absolute ethanol. Ethanol-preserved samples were transported in coolers to the laboratory for genetic analysis. 
Figure 1. A map with proportions of different Pseudomonas species found in each sampling site: Manaus and Tapajós.



\subsection{Genetic Analyses}

DNA extraction and PCR amplification were carried out in sterile conditions to prevent cross-contamination of samples during the process. Total DNA was extracted from a small piece (approximately $5 \mathrm{mg}$ ) of alcohol-preserved fish tissue by the standard protocol of Estoup et al. [23], using Chelex ${ }^{\circledR}$ resin (Bio-Rad Laboratories, Hercules, CA, USA). Chelex ${ }^{\circledR}$ is a chelating material used to purify other compounds from a tissue via ion exchange. It is often used for DNA extraction in preparation for PCR. Polar resin beads bind polar cellular components after breaking open cells, while DNA and RNA remain suspended in water solution above the Chelex ${ }^{\circledR}$. The tissue was introduced in an Eppendorf tube with $500 \mu \mathrm{L}$ of Chelex ${ }^{\circledR}$ resin $(10 \%)$ and $7 \mu \mathrm{L}$ of Proteinase $\mathrm{K}(20 \mathrm{mg} / \mathrm{mL})$. It was incubated at $55{ }^{\circ} \mathrm{C}$ for $90 \mathrm{~min}$. The DNA was dissolved in the aqueous solution. Finally, it was introduced in an oven at $100{ }^{\circ} \mathrm{C}$ during 20 min for inactivating the enzyme. The tube was stored at $4{ }^{\circ} \mathrm{C}$ or frozen at $-20{ }^{\circ} \mathrm{C}$ for long-time preservation.

A fragment of the $16 \mathrm{~S}$ rRNA gene was amplified by polymerase chain reaction (PCR), employing the Pseudomonas genus specific primers PA-GS-F (5'-GACGGGTGAGTAATGCCTA-3') and PA-GS-R (5'-CACTGGTGTTCCTTCCTATA-3') described by Spilker et al. [24] They amplify a DNA region of 618 nucleotides located between the sites 113 and 712, position and size relative to $16 \mathrm{~S}$ 
rDNA sequence of Pseudomonas aeruginosa AT2 (AB091760) [24]. The amplification reaction was performed in a total volume of $40 \mu \mathrm{L}$, including Promega (Madison, WI, USA) Buffer 1X, $2.5 \mathrm{mM}$ $\mathrm{MgCl}_{2}, 0.25 \mathrm{mM}$ dNTPs, $20 \mathrm{pmol}$ of each primer, $20 \mathrm{ng}$ of template DNA, and $1 \mathrm{U}$ of DNA Taq polymerase (Promega). The PCR conditions were the following: an initial denaturation at $95{ }^{\circ} \mathrm{C}$ for $5 \mathrm{~min}, 10$ cycles at $94{ }^{\circ} \mathrm{C}$ for $15 \mathrm{~s}$, annealing at $53{ }^{\circ} \mathrm{C}$ for $30 \mathrm{~s}$ and elongation at $72{ }^{\circ} \mathrm{C}$ for $45 \mathrm{~s}$. This was repeated for 25 cycles, increasing the elongation step at $72{ }^{\circ} \mathrm{C}$ by $5 \mathrm{~s}$ every cycle. The final extension phase was at $72{ }^{\circ} \mathrm{C}$ for $10 \mathrm{~min}$.

PCR products were visualized in $2 \%$ agarose gels with $3 \mu \mathrm{L}$ of $10 \mathrm{mg} / \mathrm{mL}$ ethidium bromide. Stained bands were excised from the gel, and DNA was purified with an Eppendorf PerfectPrep Gel CleanUp ${ }^{\circledR}$ kit prior to sequencing. After that, amplified and purified products were precipitated using standard 2-propanol precipitation and re-suspended in formamide.

Sequencing was performed in an ABI PRISM 3100 Genetic Analyzer (Applied Biosystems, Foster City, CA, USA) with BigDye 3.1 terminator system, at the Sequencing Unit of the University of Oviedo (Oviedo, Spain).

\subsection{Sequence Edition and Phylogenetic Analysis}

Sequences obtained from the 16S rRNA gene amplicons were visualized and edited employing the BioEdit Sequence Alignment Editor software [25]. Sequences were aligned with the ClustalW application [26] included in BioEdit.

The phylogenetic analysis was performed with the software MEGA 4.0 [27]. This software was employed to reconstruct the phylogenetic trees of the Pseudomonas species found in fish samples from 16S rDNA sequences. The methodology chosen was the neighbor-joining (NJ), the standard method of phylogenetic inference in DNA barcoding studies [28] because it allows to rapid analysis of large species assemblages [29]. The molecular substitution model was chosen using the software jModeltest [30] to determine the best suited model of sequence evolution and accompanying evolutionary parameter values for the data. Robustness of the NJ topology was assessed using 2,000 bootstrap replicates.

Pseudomonas species identification was made by comparing generated 16S rDNA sequences with reference sequences present in the GenBank database by means of BLAST online program [31].

\subsection{Pseudomonas Diversity Estimates}

Pseudomonas species diversity in each Amazonian location was estimated by means of ecological index (Shannon, H) using PRIMER 6 (Software package from the Plymouth Marine Laboratory, Lutton, Ivybridge, UK). The number of haplotypes (h) and nucleotide diversity $(\pi)$ were calculated with the ARLEQUIN software [32,33].

\subsection{Statistics}

To compare the proportion of contaminated fish between locations, chi-square statistics was employed. Analysis was carried out using the SPSS 13.0 software (SPSS Inc., Chicago, IL, USA). 


\section{Results and Discussion}

Positive PCR amplification was obtained with Pseudomonas specific primers for a fragment of the 16S rDNA [24] from 28 Amazonian fish out of 30 samples analyzed (93.3\%): 16 from the River Tapajòs and 12 from the River Negro. Cross-contamination of samples during the process of DNA analysis can be reasonably excluded since the two samples from Tapajòs that did not provide positive PCR amplification (Table 1) could be considered Pseudomonas-free. Sequences were very clean (an example is in Figure 2) and mixture of species was not found for any sample. This does not exclude their presence but indicates that, if other Pseudomonas were present in a sample, they were likely in a lower concentration; the PCR primers would anneal preferentially with the most abundant target DNA. The sequences are available in the GenBank public database [31] under the accession numbers JF745541-JF745568.

Figure 2. Chromatogram of a DNA sequence corresponding to the 16S rRNA gene fragment of a Pseudomonas putida (T16) found in Leporinus piau from Tapajós.

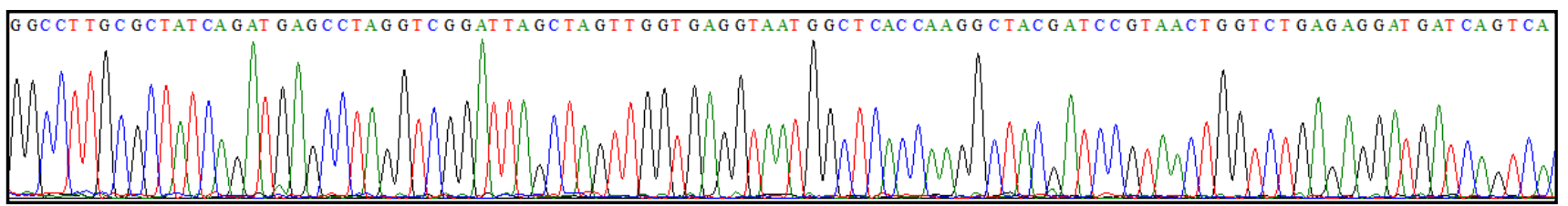

The 16S rDNA sequences obtained allowed to identifying five Pseudomonas species in Tapajós (Table 1): Pseudomonas pshychrophila, P. fragi, P. fluorescens, P. syringae and P. putida, based on $100 \%$ of similarity with other reference sequences of those species included in the GenBank. Two fish contained Pseudomonas but the species could not be identified because the alignment obtained did not yield 100\% similarity with any other Pseudomonas species included in the GenBank, therefore they were classed as Pseudomonas sp. On the other hand, Manaus fish samples carried only two Pseudomonas species: P. putida and P. pshychrophila (Table 1).

For the fish carrier, Pseudomonas contamination affected different fish species (Table 1), but association fish-Pseudomonas species could not be properly tested due to reduced number of some fish species.

The Pseudomonas found in the two locations clustered in two main branches in a phylogenetic tree (Figure 3), supported by relatively low bootstrapping. One contained Pseudomonas putida and $P$. syringae and the other clustered the other three species and the unidentified sequences, which should logically correspond to species of the same group.

Although the proportion of contaminated fish was similar in the two locations analyzed, Tapajós fish samples contained more Pseudomonas sp. species and therefore higher bacterial diversity, both ecological and genetic, than Manaus commercial fish (Figure 4). The species composition of the Pseudomonas complex found in the two locations was significantly different (Chi-square value $=19.26$, $p<0.001$ ), clearly due to much higher proportion of P. putida and P. psychrophila in Manaus and Tapajós fish, respectively (Figure 1). 
Figure 3. Neighbour-Joining tree constructed based on $16 \mathrm{~S}$ rDNA Pseudomonas sequences found in this survey. Bootstrap values (in percent).

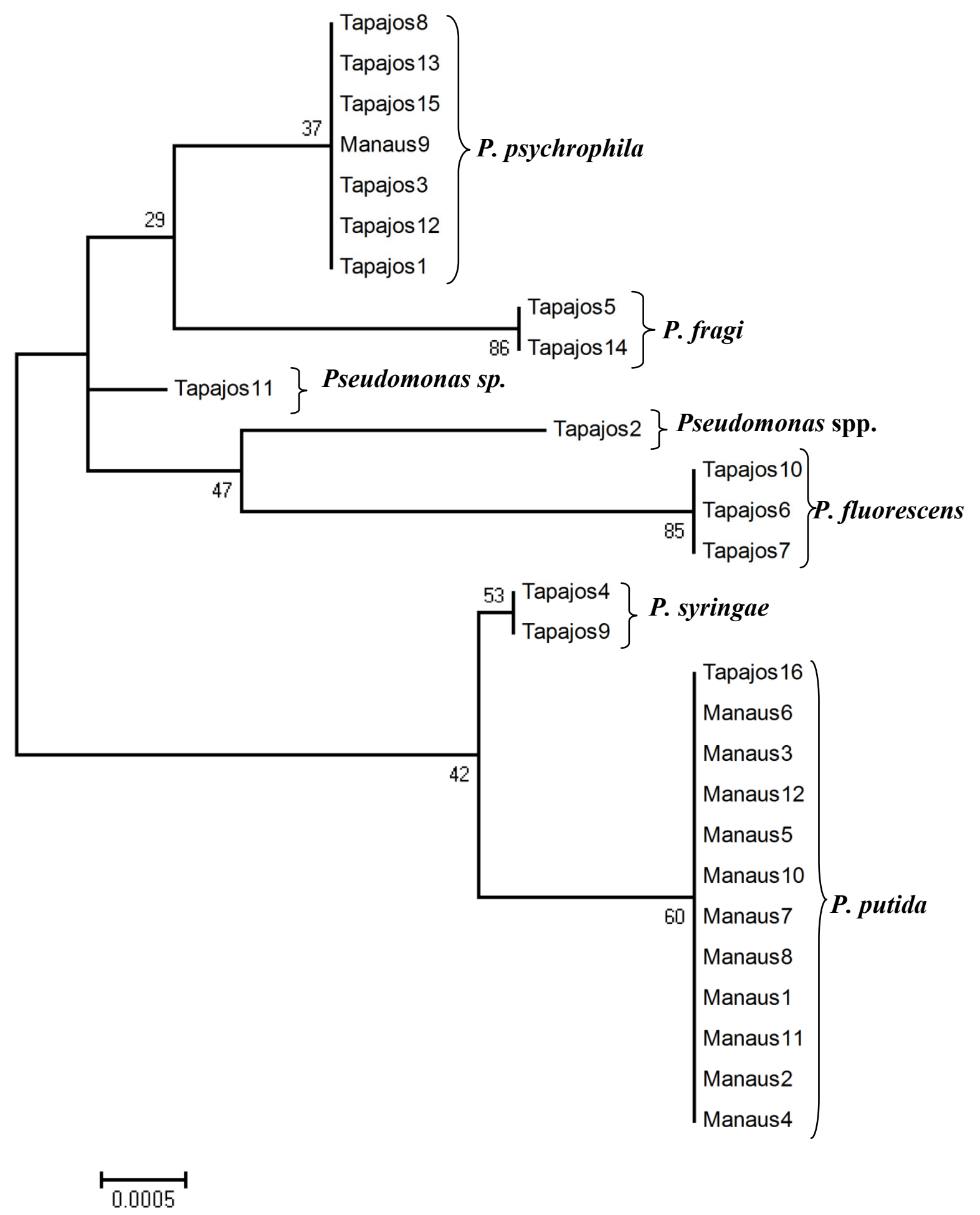


Figure 4. Diversity parameters of fishborne Pseudomonas communities from the Amazonian Tapajòs and Negro tributaries. Metagenetic $h$ and $\pi$ parameters, and Shannon index.

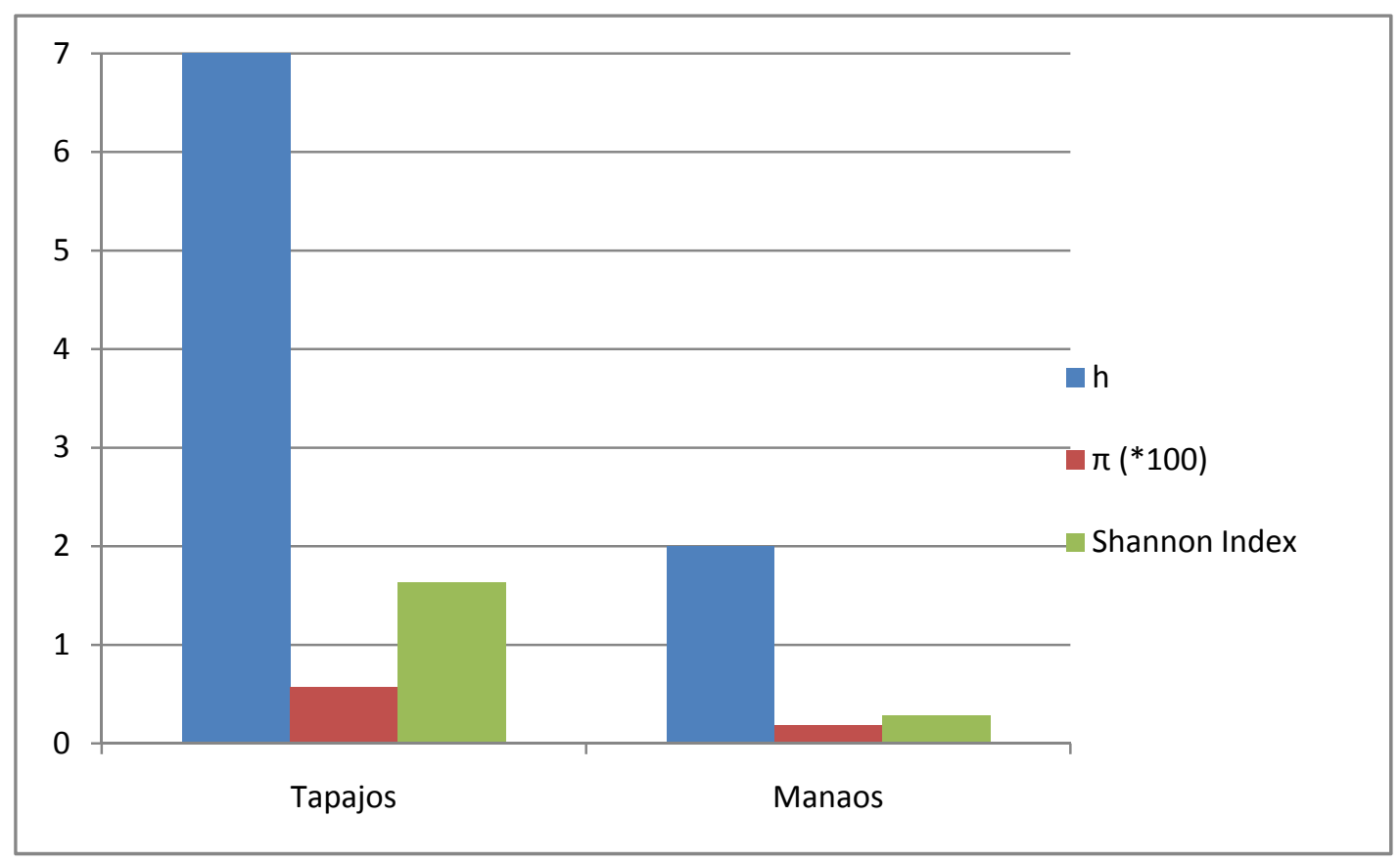

The results presented here, although based on small sample sizes, suggest that Pseudomonas are endemically present in Amazonian fish sold in local markets since most analyzed fish yielded positive PCR amplification for these bacteria. Pseudomonas aeruginosa, the most dangerous species for human health $[9,10,17]$ and especially for consumers $[13,15]$, was not detected. Therefore consumption of these fish can be considered generally safe for healthy people, at least from their Pseudomonas content.

The characteristics of the Pseudomonas species found from Brazilian fish samples (Table 2) may suggest the origin of the contamination. Fish infection in some Tapajós samples was suggested by the presence of the well-known fish pathogen $P$. fluorescens, which is considered as opportunistic pathogenic species in aquaculture [34,35], responsible for bacterial septicemia in fish. This species was present in three (16.7\%) samples from Tapajós, but in none from Manaus (Figure 1). Pseudomonas infections in fish are promoted by different stressors [6,36]. Environmental stress produced by mining has been reported in the River Tapajós [37], and could contribute to facilitate fish infection by opportunistic Pseudomonas.

P. putida was found in most Manaus samples (Figure 1) and in only one sample from Tapajós. Different Pseudomonas species have been associated with seafood (including chilled fish) spoilage, for example P. fragi [6], therefore the likely origin of contamination of these samples could be seafood manipulation, long time of storage before selling or simply opportunistic growth of these bacteria on fish exposed without protection in the open-door local markets. P. putida infections have also been reported in fish species, for example in farmed rainbow trout [38], also associated to stress, therefore this last possibility cannot be totally ruled out. P. psychrophila grows in cold conditions $[39,40]$, unusual in the natural tropical Amazonian environment; they could be an opportunistic colonizer during the storage in cold rooms previous to selling in the market. Finally, P. syringae is a plant 
pathogen which can infect a wide range of plant species; more than any mineral or other organism is responsible for the surface frost damage in plants exposed to the environment [41]; like P. psychrophila tends to be favored by wet and cool conditions [41], being more probable that appear like an opportunistic colonizer during the storage in cool rooms.

Table 2. Characteristics of the Pseudomonas species found from commercial Amazonian fish and potential risk for humans.

\begin{tabular}{ccc}
\hline Pseudomonas species & Characteristics & Pathogenesis reported for humans \\
\hline P. fluorescens & Opportunistic pathogen in fish [42] & Oncology patients [43] \\
P. fragi & Seafood spoilage [6,44] & No published data about this \\
P. psychrophila & Opportunistic microbiota [6] & No * \\
P. putida & Seafood spoilage [44] & Immunodepressed patients [45] \\
P. syringae & Cosmopolitan opportunist [46] & Nosocomial infections [47] \\
* They cannot survive at temperatures above 32 ${ }^{\circ} \mathrm{C}[39,41]$, and therefore cannot grow in humans where \\
normal body temperature is $37{ }^{\circ} \mathrm{C}$.
\end{tabular}

From the phylogenetic point of view, the tree obtained grouped the identified species consistently with previous phylogenetic studies of the genus [47,48]. The same marker, $16 \mathrm{~S}$ rRNA gene, was used together with other three genes, since although this is a powerful tool for genus assignments, it does not discriminate sufficiently at the inter-species level [49]. In this case the discrimination level of $16 \mathrm{~S}$ rRNA gene is enough to determine the contamination present in fishes with different species of Pseudomonas.

Although we have not found the most dangerous species, the Pseudomonas found in our study could be potentially harmful for vulnerable or immunodepressed consumers (Table 2). Infections by P. fluorescens and P. putida had been reported in old studies [43-45,50] (and references therein), and were confirmed later. P. fluorescens is a potential pathogen due to their capacity of adhesion to nerves [50], and outbreaks in oncology patients have been discovered [43]. On the other hand, P. putida bacteremia seemed to be infrequent and affect mainly immunocompromised patients, with a good prognosis since most cases were cured [45]; however, recent emergent multidrug-resistant and carbapenem-resistant. P. putida isolates cause difficult-to-treat nosocomial infections in seriously ill patients [51]. In brief, these species could cause problems in vulnerable people and do not represent a serious threat for healthy consumers [52], but using a precautionary approach it could be wise to start considering them for future seafood tests. The presence of these pathogens in the products tested here does not mean that they are a risk for consumers; in general Pseudomonas sp. represents a hazard for the health when its number exceeds $10^{6}-10^{7} \mathrm{CFU} / \mathrm{g}$ of product $[11,12,15,17]$ but CFU has not been quantified here. Rather these results could be considered an exploratory work on presence/absence of Pseudomonas. If routine surveys were undertaken they should include quantification of the bacteria concentration. RT-PCR based methods could be employed since they can estimate the number of DNA molecules present in a sample. These methods are relatively cheap nowadays and the sequencing cost per sample in our study was approximately $3 €$ (real cost). However, the analysis of foodborne bacteria is being revolutionized with new sequencing technologies such as NGS [53], and prospects are of better prices for large-scale 
analysis. On the other hand, this type of PCR-based methods allow to detecting extremely low number of microorganisms based on the production of specific gene copies of a microorganism in question, but it does not distinguish living bacteria from dead cells. Since PCR methodology is rapid (a few hours), additional tests based on the count of total viable microorganisms could be used after initial detection and identification by PCR. Examples are Standard Plate Count [54], determination of most probable number of viable bacteria [55], methods based on fluorescence techniques [56] or direct counting at the microscope [57].

\section{Conclusions}

The possible presence of Pseudomonas in fish and seafood should be considered when food imports arrive from countries or areas with Pseudomonas endemism and high prevalence of enterotoxigenic-derived diseases. We suggest that routine tests for Pseudomonas could be included in the battery of tests aimed at controlling the bacteriological quality of imported fish. PCR-based methodologies, like those employed in this study, are easy and fast and could be considered as a complementary tool to bacterial cultivation.

\section{Acknowledgments}

This study has been funded by the Spanish Agency of International Cooperation for Development (AECID) Project D/023514/09. We are grateful to Vanessa Gomes, Ione Ginuino, Gema E. Adan and Eduardo del Rosal for collaboration in sampling. Ivan G. Pola helped with laboratory work.

\section{Conflicts of Interest}

The authors declare no conflict of interest.

\section{References}

1. Saint-Paul, U.; Zuanon, J.; Villacorta-Correa, M.A.; García, M.; Fabré, N.N.; Berger, U.; Junk, W.J. Fish communities in central amazonian white- and blackwater floodplains. Environ. Biol. Fishes 2000, 57, 235-250.

2. Fernandes, C.C.; Podos, J.; Lundberg, J.G. Amazonian ecology: Tributaries enhance the diversity of electric fishes. Science 2004, 305, 1960-1962.

3. Ardura, A.; Pola, I.G.; Linde, A.R.; Garcia-Vazquez, E. DNA-based methods for species authentication of Amazonian commercial fish. Food Res. Int. 2010, 43, 2295-2302.

4. FAO/WHO: Food and Agriculture Organization of the United Nations/ World Health Organization. Microbiological Risk Assessment Series. In Risk Characterization of Microbiological Hazards in Food. Guidelines; WHO: Geneva, Switzerland, 2009; Volume 17, p. 116.

5. Sakata, T. Microflora of Healthy Animals. In Methods for the Microbiological Examination of Fish and Shellfish Chichester; Austin, B., Austin, D.A., Eds.; Ellis Horwood Ltd.: England, UK, 1989; pp. 141-163. 
6. Gram, L.; Huss, H.H. Fresh and Processed Fish and Shellfish. In The Microbiological Safety and Quality of Foods; Lund, B.M., Baird-Parker, A.C., Gould, G.W., Eds.; Chapman \& Hall: London, UK, 2000; pp. 472-506.

7. Gram, L.; Ravn, L.; Rasch, M.; Bruhn, J.B.; Christensen, A.B.; Givskov, M. Food spoilage-interactions between food spoilage bacteria. Int. J. Food Microbiol. 2002, 78, 79-97.

8. Nyenje, M.E.; Odjadjare, C.E.; Odjadjare, L.; Tanih, N.F.; Green, E.; Ndip, R.N. Foodborne pathogens recovered from ready-to-eat foods from roadside cafeterias and retail outlets in Alice, Eastern Cape Province, South Africa: Public health implications. Int. J. Environ. Res. Public Health 2012, 9, 2608-2619.

9. Bagshaw, S.M.; Laupland, K.B. Epidemiology of intensive care unit-acquired urinary tract infections. Curr. Opin. Infect. Dis. 2006, 19, 67-71.

10. Zilberberg, M.D.; Shorr, A.F. Epidemiology of healthcare-associated pneumonia (HCAP). Semin. Respir. Crit. Care Med. 2009, 30, 10-15.

11. Mena, K.D.; Gerba, C.P. Risk assessment of Pseudomonas aeruginosa in water. Rev. Environ. Contam. Toxicol. 2009, 201, 71-115.

12. Jiwa, S.F.H.; Krovacek, K.; Wadstrom, T. Enterotoxigenic bacteria in food and water from an ethiopian community. Appl. Environ. Microbiol. 1981, 41, 1010-1019.

13. Jertborn, M.; Svennerholm, A.M. Enterotoxin-producing bacteria isolated from Swedish travellers with diarrhoea. Scand. J. Infect. Dis. 1991, 23, 473-479.

14. Bockemühl, J.; Fleischer, K.; Bednarek, I. A cholera-like illness in a traveller due to a mixed infection with enterotoxigenic Escherichia coli, Vibrio parahaemolyticus and Pseudomonas aeruginosa. Infection 1983, 11, 272-274.

15. Adlard, P.A.; Kirov, S.M.; Sanderson, K.; Cox, G.E. Pseudomonas aeruginosa as a cause of infectious diarrhoea. Epidemiol. Infect.1998, 121, 237-241.

16. Wong, S.; Street, D.; Delgado, S.I.; Klontz, K.C. Recalls of foods and cosmetics due to microbial contamination reported to the U.S. Food and Drug Administration. J. Food Prot. 2000, 63, 1113-1116.

17. Craun, G.F.; Brunkard, J.M.; Yoder, J.S.; Roberts, V.A.; Carpenter, J.; Wade, T.; Calderon, R.L.; Roberts, J.M.; Beach, M.J.; Roy, S.L. Causes of outbreaks associated with drinking water in the United States from 1971 to 2006. Clin. Microbiol. Rev. 2010, 23, 507-528.

18. Product Inspection of Imported Fish. Csnsdian Food Inspection Agency. 2013. Available online: http://www.inspection.gc.ca/english/fssa/fispoi/import/pol/procprode.shtml (accessed on 26 August 2013).

19. Microbiological Criteria. Health and Consumers. European Commission. 2011. Available online: http://ec.europa.eu/food/food/biosafety/salmonella/microbio_en.htm (accessed on 26 August 2013).

20. Food Safety and Inspection Service. United States Department of Agriculture. Available online: http://www.fsis.usda.gov/ (accessed on 26 August 2013).

21. Bennett, A.R.; Greenwood, D.; Tennant, C.; Banks, J.G.; Betts, R.P. Rapid and definitive detection of Salmonella in foods by PCR. Lett. Appl. Microbiol. 1998, 26, 437-441.

22. Wang, R.-F.; Cao, W.W.; Cerniglia, C.E. A universal protocol for PCR detection of 13 species of foodborne pathogens in foods. J. Appl. Microbiol. 1997, 83, 727-736. 
23. Estoup, A.; Largiader, C.R.; Perrot, E.; Chourrout, D. Rapid one-tube DNA extraction for reliable PCR detection of fish polymorphic markers and transgenes. Mol. Mar. Biol. Biotechnol. 1996, 5 , 295-298.

24. Spilker, T.; Coenye, T.; Vandamme, P.; LiPuma, J.J. PCR-based assay for differentiation of Pseudomonas aeruginosa from other Pseudomonas species recovered from cystic fibrosis patients. J. Clin. Microbiol. 2004, 42, 2074-2079.

25. Hall, T.A. BioEdit: A user-friendly biological sequence alignment editor and analysis program for Windows 95/98/NT. Nucleic Acids Symp. Ser. 1999, 41, 95-98.

26. Thompson, J.D.; Higgins, D.G.; Gibson, T.J. Clustal-W, Improving the sensitivity of progressive multiple sequence alignment trough sequence weighting, position-specific gap penalties and weight matrix choice. Nucleic Acids Res. 1994, 22, 4673-4680.

27. Tamura, K.; Dudley, J.; Nei, M.; Kumar, S. MEGA4: Molecular Evolutionary Genetics Analysis (MEGA) software version 4.0. Mol. Biol. Evolut. 2007, 24, 1596-1599.

28. Hebert, P.; Cywinska, A.; Ball, S.; deWaard, J. Biological identification through DNA barcodes. Proc. R. Soc. B: Biol. Sci. 2003, 270, 313-321.

29. Kumar, S.; Gadadkar, S. Efficiency of the neighbour-joining method in reconstructing deep and shallow evolutionary relationships in large phylogenies. J. Mol. Evolut. 2000, 51, 544-553.

30. Posada, D. jModelTest: Phylogenetic model averaging. Mol. Biol. Evolut. 2008, 25, 1253-1256.

31. National Center for Biotechnology Information. Available online: http://www.ncbi.nlm.nih.gov/ (accessed on 26 August 2013).

32. Nei, M. Molecular Evolutionary Genetics; Columbia University Press: New York, NY, USA, 1987; p. 512.

33. Excoffier, L.; Laval, G.; Schneider, S. Arlequin (version 3.0): An integrated software package for population genetics data analysis. J. Evol. Bioinform. Online 2005, 1, 47-50.

34. Shiose, J.; Wakabayashi, H.; Tominaga, M.; Egusa, S. A report on a disease of cultured carp due to a capsulated Pseudomonas. Fish Pathol. 1974, 9, 79-83.

35. Alderman, D.J.; Polglase, J.L. Pathogens, Parasites and Commensals. In Freshwater CrayfishBiology, Management and Exploitation; Holdich, D.M., Lowry, R.S., Eds.; Timber Press: Portland, OR, USA, 1998; pp. 168-187.

36. Kusuda, R.; Toyoshima, R. Characteristics of a pathogenic Pseudomonas isolated from cultured yellowtail. Fish Pathol. 1976, 1, 133-139.

37. Uryu, Y.; Malm, O.; Thornton, I.; Payne, I.; Cleary, D. Mercury contamination of fish and its implications for other wildlife of the Tapajós Basin, Brazilian Amazon. Conserv. Biol. 2001, 15, $438-446$.

38. Altinok, I.; Kayisa, S.; Capkin, E. Pseudomonas putida infection in rainbow trout. Aquaculture 2006, 261, 850-855.

39. Yumoto, I; Kusano, T.; Shingyo, T.; Nodasaka, Y.; Matsuyama, H.; Okuyama, H. Assignment of Pseudomonas sp. strain E-3 to Pseudomonas psychrophila spp. nov., a new facultatively psychrophilic bacterium. Extremophiles 2001, 5, 343-349.

40. Morita, R.Y. Psychrophilic bacteria. Bacteriol. Rev.1975, 39, 144-167.

41. Hirano, S.S.; Upper, C.D. Population biology and epidemiology of Pseudomonas syringae. Annu. Rev. Phytopathol. 1990, 28, 155-177. 
42. Bruno, D.W.; Ellis, A.E. Salmonid Disease Management. Dev. Aquac. Fish. Sci. 1996, 29, $729-824$.

43. Hsueh, P.R.; Teng, L.J.; Pan, H.J.; Chen, Y.C.; Sun, C.C.; Ho, S.W.; Luh, K.T. Outbreak of Pseudomonas fluorescens bacteremia among oncology patients. J. Clin. Microbiol. 1998, 36, 2914-2917.

44. Von Graevenitz, A.; Weinstein, J. Pathogenic significance of Pseudomonas fluorescens and Pseudomonas putida. Yale J. Biol. Med. 1971, 44, 265-273.

45. Yoshino, Y.; Kitazawa, T.; Kamimura, M.; Tatsuno, K.; Ota, Y.; Yotsuyanagi, H. Pseudomonas putida bacteremia in adult patients: five case reports and a review of the literature. J. Infect. Chemother. 2011, 17, 278-282.

46. Timmis, K.N. Pseudomonas putida: A cosmopolitan opportunist par excellence. Environ. Microbiol. 2002, 4, 779-781.

47. Yamamoto, S.; Kasai, H.; Arnold, D.L.; Jackson, R.W.; Vivian, A.; Harayama, S. Phylogeny of the genus Pseudomonas: Intrageneric structure reconstructed from the nucleotide sequences of gyrB and rpoD genes. Microbiology 2000, 146, 2385-2394.

48. Franzetti, L.; Scarpellini, M. Characterisation of Pseudomonas spp. isolated from foods. Ann. Microbiol. 2007, 57, 39-47.

49. Mulet, M.; Lalucat, J.; García-Valdés, E. DNA sequence-based analysis of the Pseudomonas species. Environ. Microbiol. 2010, 12, 1513-1530.

50. Picot, L.; Mezghani-Abdelmoula, S.; Merieaua, A.; Lerouxb, P.; Cazina, L.; Orangea, N.; Feuilloley, M.G.J. Pseudomonas fluorescens as a potential pathogen: Adherence to nerve cells. Microbes Infect. 2001, 3, 985-995.

51. Kim, S.E.; Park, S.H.; Park, H.B.; Park, K.H.; Kim, S.H.; Jung, S.I.; Shin, J.H.; Jang, H.C.; Kang, S.J. Nosocomial Pseudomonas putida bacteremia: High rates of carbapenem resistance and mortality. Chonnam Med. J. 2012, 48, 91-95.

52. Gilardi, G.L. Infrequently encountered Pseudomonas species causing infection in humans. Ann. Int. Med. 1972, 77, 211-215.

53. Wilson, M.R.; Allard, M.W.; Brown, E.W. The forensic analysis of foodborne bacterial pathogens in the age of whole-genome sequencing. Cladistics 2013, 29, 449-461.

54. LeChevallier, M.W.; Seidler, R.J.; Evans, T.M. Enumeration and characterization of standard plate count bacteria in chlorinated and raw water supplies. Appl. Environ. Microbiol. 1980, 40, 922-930.

55. Hihgsmith, A.K.; Abshire, R.L. Evaluation of most-probable-number technique for the enumeration of Pseudomonas aeruginosa. Appl. Microbiol. 1975, 30, 596-601.

56. Breeuwer, P.; Abee, T. Assessment of viability of microorganisms employing fluorescence techniques. Int. J. Food Microbiol. 2000, 55, 193-200.

57. Kogure, K.; Simidu, U.; Taga, N. A tentative direct microscopic method for counting living marine bacteria. Can. J. Microbiol. 1979, 25, 415-420.

(C) 2013 by the authors; licensee MDPI, Basel, Switzerland. This article is an open access article distributed under the terms and conditions of the Creative Commons Attribution license (http://creativecommons.org/licenses/by/3.0/). 